\title{
Instituting dispute resolution procedures in the Apostolic Faith Mission in Zimbabwe church
}

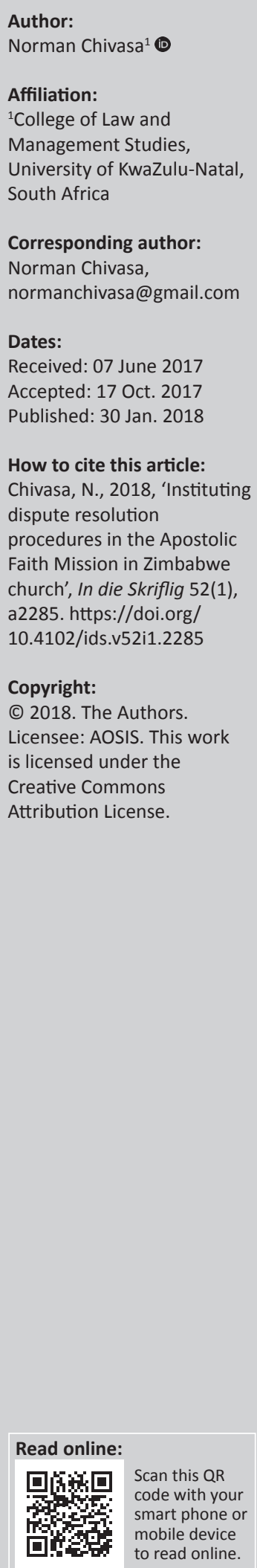

\begin{abstract}
The need to institute dispute resolution procedures in the Apostolic Faith Mission (AFM) in Zimbabwe church informs this study. Remarkably, one of the most critical problems facing the AFM in Zimbabwe church is intrachurch disputes, which manifest in diverse forms such as pastors' transfers disputes, election disputes and pastors' performance disputes. Such disputes have produced undesirable consequences not only for pastors but also for the wellbeing of the church in general. Intrachurch disputes require internal mechanisms to manage them so that constructive rather than destructive results are achieved. To do this, internal dispute resolution procedures become critical as they provide a framework for the constructive resolution of disputes. The lived experience of disputes in the AFM in Zimbabwe church confirms the appropriateness of systems theory, which states that social institutions are vulnerable to disharmony owing to differing interacting elements. To mitigate the negative impact associated with disputes, this study proposes the need to institute dispute resolution procedures in the AFM in Zimbabwe, because the church currently relies only on disciplinary procedures to address disputes. The study further emphasises that instituting dispute resolution procedures will help the church handle disputes from within its ranks without necessarily involving local courts, which may have negative financial and relationship implications. Finally, the study develops a model for dispute resolution procedures as an instrument that can assist local churches in AFM in Zimbabwe church to handle disputes as and when they arise.
\end{abstract}

\section{Introduction}

When I first conducted a research on the Apostolic Faith Mission (AFM) in Zimbabwe church in 2007, I had several presuppositions about the way in which this church handles disputes involving pastors. Some of the presuppositions were that the AFM in Zimbabwe church was antagonistic in its approach to disputes involving pastors, and that the church had lost touch with principles that govern the resolution of intrachurch disputes. I also came to believe that apart from perpetuating antagonistic relations, no real guidelines were put in place for addressing disputes involving pastors except for disciplinary procedures. My initial fieldwork inclined me towards the view that this specific denomination which existed for more than nine decades in Zimbabwe by 2007, had not come up with a framework for handling disputes. For this reason, I was working from the premise that the church under review was in desperate need of a dispute resolution centre to help train pastors in dispute resolution and peer mediation skills (Chivasa 2012:70).

However, in 2017, I had the opportunity to scrutinise the Policy Document of the AFM in Zimbabwe church, and especially the code of conduct and grievance handling procedures (CCGHP), Chapter 14. I noticed that Chapter 14 was set to enforce disciplinary measures in cases of acts of misconduct. Apart from that, I began to understand that Chapter 14 was designed to outline acts of misconduct, as understood by the church under review. It also prescribed disciplinary procedures following an act of misconduct (Chapter 14.7 to 14.8.5).

Paradoxically, there is no dispute resolution procedure in the CCGHP, although one of the objectives (14.2.2) was 'to enable church leadership, pastors, lay workers and general staff settle disputes amongst themselves'. Since the CCGHP was only set for addressing acts of misconduct, to analyse systematically the disciplinary procedures of the AFM in Zimbabwe, a paper entitled 'Handling pastoral misconduct and discipline in the AFM in Zimbabwe' was developed. In this paper, I noticed several issues I had not taken notice of in 2007. Now I managed to understand how different acts of misconduct, disputes and grievances result from conflict and how the church had taken measures to address the misconduct by instituting disciplinary procedures. I also noticed that the disciplinary procedures recognised that pastors and ordinary church members are not perfect and hence the church instituted a procedure to address acts of misconduct that 
may arise. My analysis revealed that the disciplinary procedures were not only adversarial in their approach to acts of misconduct, but were not ideal for resolving disputes (Chivasa 2017:3). This follow-up paper argues for the need to institute dispute resolution procedures to provide disputants with a platform where they can participate in search of a mutually satisfying solution to a dispute.

The motivation to conduct this analysis was sparked by two factors. The first was the unavailability of dispute resolution procedures in the Constitution and Regulations of the AFM in Zimbabwe church. The second was that no efforts to date have been made to assess systematically the need to institute dispute resolution procedures in the church under review. As such the current study attempts to fill this gap and it makes a case for the need to institute dispute resolution procedures to complement the disciplinary procedures currently in use in the AFM in Zimbabwe. To interrogate systematically the need for dispute resolution procedures, this research was guided by the following three questions: What is involved in dispute resolution? Which factors require consideration when instituting dispute resolution procedures in the AFM in Zimbabwe? How significant is the dispute resolution procedure?

Consequently, this study is structured as follows: the first section describes the context of the study, which is augmented by the clarification of key concepts. The second section reviews the theoretical framework that underpins this study. The third section describes the methodology and events leading to the development of this research. The fourth section examines factors to be taken into consideration when instituting dispute resolution procedures followed by an examination of the significance of the dispute resolution procedures. The concluding fifth section provides recommendations resulting from the study in totality.

\section{The context}

Local newspapers in Zimbabwe contain numerous stories relating to disputes in the AFM in Zimbabwe. Although it is not uncommon to encounter disputes in any organisation, even a Christian church, it is worrying to note that the superiority of disputes in the AFM in Zimbabwe involve church leaders such as pastors and overseers. The increasing number of disputes involving leadership in the AFM in Zimbabwe has been so dramatic in the past decades that a single search in 2016 via the Google search engine, using the phrase 'AFM in Zimbabwe disputes and pastors' transfers', elicited results including numerous articles in local newspapers on this subject. The AFM in Zimbabwe church's Constitution and Regulations, Chapter 10.4, states that 'the provincial committee may transfer pastors from one assembly to another within its province'. Historically this clause has sparked various disputes in the church. Many assemblies and their pastors in the AFM in Zimbabwe have waged bitter wars with overseers and provincial committees owing to this clause. During informal conversations informants reported that the vast proportion of disputes involved pastors' transfers from one assembly to another. Even though the Constitution and Regulations outline that the provincial committee has the prerogative to transfer pastors, all informants believe the church will continue to experience disputes as historically the plurality of senior pastors have declined a transfer if it involves moving from an urban assembly that is perceived as being more affluent.

To give up-to-date examples of the most typical disputes experienced in the AFM in 2016, I refer to seven articles elicited by the Google search mentioned in the previous paragraph. These seven articles were carried in local newspapers in Zimbabwe:

- 'AFM fires senior pastor, closes assembly' (Mhlanga 2016a);

- 'Violence mars AFM services as congregants block pastor transfer' (Mhlanga 2016b);

- 'AMH Voices: AFM doesn't belong to anyone, but everyone' (Koni 2016);

- 'AFM leadership row spills into court' (Zhakata 2016);

- 'AFM pastor, congregants clash' (Post Reporter 2016);

- 'AFM conference sidesteps local conflicts' (Bulla 2016);

- 'AFM church members in ugly fight' (Gukutikwa 2016).

The most notable issues are incidents of violent behaviour (as exhibited in the second and the sixth newspaper headlines above) especially by some congregants against provincial committee members in their bid to address pastors' transfer disputes. Such incidences are indicative of the scale of the problem in a church.

As if that is not enough, other searches via the Google search engine using the phrase 'AFM in Zimbabwe and elections disputes' over the period 2015 and 2016 elicited several articles in local newspapers in Zimbabwe. The reason for conducting a search in 2015 is that the AFM in Zimbabwe conducted elections in that year, in which the current church president and overseers were elected..$^{1}$ In the aftermath of church presidential elections in 2015, some church members and pastors teamed up, objecting against the outcome of the elections (ZimEye 2015a). Local newspaper headlines in Zimbabwe point to the scale of the problem, for example:

- 'Overstaying AFM leader splits church' (Staff Reporter 2015);

- 'AFM church hires NIKUV to rig pastors' election' (ZimEye 2015b);

- 'AFM church in dirty election rigging: Court papers' (ZimEye 2015a);

- 'Disgruntled members sue AFM executive' (Murwira 2015);

- 'When the church becomes a battlefield' (Bulla 2015);

- 'AFM leadership row spills into court' (Zhakata 2016);

1.Office bearers of the AFM in Zimbabwe are elected triennially. The overseer is elected from amongst pastors who have been in the ministry for a period of at least elected from amongst pastors who have been in the ministry for a period of at least 10 years and is elected from the provincial workers council, comprising all pastors, elders and deacons who are members of this council (Constitution and Regulations, Chapter 9). The church president is elected at a workers' council in which all representatives from various provinces are gathered. The minimum age for one to qualify for the post of a church president is 50 years and presidents are elected from amongst the ranks of provincial overseers (Chapter 13). 
- 'AFM seeks leadership change' (Razemba 2016);

- 'AFM conference sidesteps local conflicts' (Bulla 2016).

As can be seen from these headlines, the scale of the problem is significant. With regard to the second headline, Nikuv International Projects, an Israelite security company, for example, was one of the 12 bidders that responded to a call by the Zimbabwe Electoral Commission (ZEC) to supply the commission with biometric registration kits and software in 2013. Subsequently, after winning the bid, the security firm was fingered as having aided in the defeat of the main opposition against the ruling party, which won in the 2013 national elections (ZimEye 2017). In the case of the AFM it should not be taken literally that the church allegedly used Nikuv to rig church elections, as this allegation is meant to register discontent against the outcome of the election results in the church under review. It is the perception that elections were not free and fair in the context of the church that gave birth to battles between those who won and those who lost the election. From my perspective, the fact that the AFM in Zimbabwe is experiencing disputes is not really a cause for concern (this is discussed further in the subsequent section). The main problem, as one AFM member reported, is that 'church leadership has failed to deal with these issues [electoral disputes and pastors transfer related disputes] for a long time' (Koni 2016). It is against this background that the current study argues for the need to institute dispute handling procedures since disciplinary procedures may not ideally handle disputes relating to pastors' transfers or elections.

\section{Clarification of primary concepts}

This section clarifies key concepts which are forerunners to the problem under investigation.

\section{Dispute}

To avoid ambiguities associated with the use of the noun dispute in everyday life, this study relies on the dictionary definition and those authorities whose definitions are closely aligned with dictionary versions. In certain circles, dispute is used interchangeably with conflict. This study relies on the assumption that a dispute is not the same as a conflict, although they cross paths. The Cambridge Dictionary online defines dispute as 'an argument or disagreement, especially an official one between, for example, workers and employers or two countries with a common border' (Cambridge Dictionary 2017). In addition, the Business Dictionary (2017) defines dispute as 'an official argument or disagreement, which occurs in the context of a company or organization'.

Miller and Sarat (1981:52) define dispute by differentiating it from a grievance. They understand grievance as the entry point into a dispute. For them, a grievance is a demand or claim for the perceived entitlement, right or resource. At the point when a person who is supposed to accept a claim rejects it, a grievance translates into a dispute. Within that framework, Miller and Sarat (1981:53) define a dispute as a situation involving two or more parties with conflicting claims to the same resource or entitlement. In the AFM in Zimbabwe church, the most common disputes relate to pastors' transfers and elections.

\section{Dispute resolution procedure}

Dispute resolution procedures is a mutually participatory in the parties collaboratively work together in search of a mutually satisfying solution to the dispute (Assefa 2001:337). Following dispute resolution procedures, a mediator can be called in to facilitate the process to create a confidential, fair and safe atmosphere for disputants to resolve their issues (Justice Connect 2015:5).

\section{Disciplinary procedures}

Churches, like any other group or association, have an obligation to place offending members under discipline through disciplinary procedures. These procedures should be stated in the church's constitution. As such, disciplinary procedures are mechanisms put in place by an institution such as a church, and are aimed at removing, suspending, or putting the offender under censure and, in a worst-case scenario, to ostracise the offender. Disciplinary procedures follow a systematic process, and are invoked whenever individual members or groups in a church have breached certain rules that govern a specific church group (Justice Connect 2015:2,4).

\section{Systems theory}

This study is informed by systems theory. A comprehensive analysis of this theory is not possible in this article due to space restrictions. Briefly, systems theory establishes a set of lenses through which the present study sought to understand why churches experience disputes and what ought to be done to mitigate the negative impact of intrachurch disputes. The primary purpose of reviewing this theory is to come up with strategies with which the church can cope with emerging disputes involving both ordinary members and church leaders. Important to note about churches is that a church 'is a group of people who profess their faith in Jesus Christ' (Chivasa 2017:2). This fact makes them fertile ground for the application of a systems approach. The existing interactions and interdependence between individuals and groups in a church renders systems theory appropriate as it helps to analyse the dynamics surrounding systems (whether closed or open).

Systems theory was the brainchild of a biologist named Ludwig von Bertalanffy (1968:20; cf. Malhadas 2010:8; Schellenberg 1996:72). In his book, General systems theory, Von Bertalanffy (1968:33), described systems as 'complexes of elements standing in interaction'. He ascribes systems as being either 'closed or open'. While he expresses this view, Von Bertalanffy emphasises that closed systems are not affected by the environment whereas open systems are always evolving because of their susceptibility to environmental factors. Like organisms, he emphasises, open systems are fundamentally in the process of build-up and 
breakdown and so on. He promulgates the notion that open systems have the capacity to 'develop towards states of increased order and organization' and in so doing open systems can achieve a state of equilibrium (1968:41). This study focuses on open systems.

Systems theory has been applied in various disciplines such as biology, engineering and the social sciences. In the social science, systems theory is premised on the assumption that a social institution involves a set of interdependent parts organised into a unity. In other words, a social institution is like a system that is organised around different interacting and interdependent parts. Schellenberg (1996:72) notes that the various parts of a system do not always work in harmony, suggesting that the equilibrium in social institutions can be out of balance at any given moment. He concludes that when equilibrium is put out of balance the system is no longer experiencing harmony. From the systems theory perspective, disharmony is a healthy experience provided that the system has the capacity to restore the equilibrium into balance.

When applied to the AFM in Zimbabwe, systems theory brings to the fore the fact that the church is like a system as it comprises various parts interacting at various levels. These parts involve ordinary church members, lay workers, pastors, overseers and the church president. The fact that the church comprises individuals with different personalities, likes and dislikes, and objectives puts the church at the unavoidable risk of experiencing disputes. Thus, through a systems theory lens, the occurrence of a dispute is not an unhealthy situation because social institutions are susceptible to friction, tension or disagreements due to the many different individuals and groups interacting. It follows that disputes are part of the lifeblood of any social institution. The mere fact that the AFM in Zimbabwe has, up to this point, been able to organise itself into a church group with structures and mechanisms for the purposes of maintaining harmony and order is acknowledgement that disputes are inevitable. Of greater importance, as this study demonstrates, is for the church to institute dispute resolution mechanisms, rather than fight to prevent disputes from occurring.

\section{Methodological note}

The primary purpose of this study is to argue for the need to institute dispute handling procedures in the church under review. This study is predominantly qualitative in that documentary review, informal conversations and participant observations were employed and they yielded data which were analysed to inform this study. To identify informants for informal conversations, convenient and purposive sampling techniques were instrumental. Not every member of the AFM in Zimbabwe I came across was considered suitable. I used purposive and convenience sampling to target pastors, elders and deacons. These sampling techniques proved useful to elicit data from pastors and lay leaders. I considered this group of informants as experts in ongoing dispute resolution processes in the church under review. As Duve and Maitireyi (2011) note, 'data are the facts, figures and other materials, past and present, that serve as the basis for study and analysis'. Documents such as the Constitution and Regulations and the Policy Document of the AFM in Zimbabwe were reviewed because of the advantage of their being objective with little room for manipulation since they represent the official position of the church under review. Literature on the AFM in Zimbabwe and grey literature on disputes in the AFM in Zimbabwe church were reviewed, based on their advantage of appraising this study with current and existing dynamics relating to disputes experienced in the AFM in Zimbabwe. To identify grey literature using the Google search engine, I used the snowball technique. The inclusion criteria for selecting literature involved key concepts such as AFM in Zimbabwe and disputes. Also, as an active member of the church under review for a period amounting to 31 years, I used my experience to select sources of disputes, such as pastors' transfers, electoral disputes or wrangles over enriching assemblies in urban centres, to cite but a few.

\section{Development of the research}

My interest in the AFM in Zimbabwe church began in 2007 when I conducted a research project for a dissertation for my master's degree in conflict resolution and peace studies. As someone who had served in the AFM in Zimbabwe church as a member for 31 years and for 12 years as a minister of religion in active ministry, a long history of contact with the church under review, I was able to understand the dynamics around issues of conflict and misconduct. I was at one point a provincial youth leader as well as a member of both Masvingo provincial committee and council. A provincial committee comprises seven members: the provincial overseer (who is elected triennially), the deputy, secretary, and four other committee members (including the provincial youth leader who represents the interests of the youths). A provincial council comprises all seven members from each of the local churches that are found in each province. A province in the AFM in Zimbabwe does not fall within the political boundaries. For instance, Zimbabwe has 10 political provinces whereas the AFM in Zimbabwe has 29 provinces (Madziyire \& Risinamhodzi 2015:5-6).

During these 31 years as a member, plus 12 years of active ministry, I managed to establish networks with a wide range of people in the church and I participated in numerous activities as one of the leaders. I convened and facilitated meetings at local church level and participated in meetings at provincial level. Some of the meetings involved conflict and acts of misconduct, some involving ordinary members and others involving pastors. I also had access to information both as a chairperson of the local church body as well as informally, but mostly through provincial council meetings, which addressed conflict and moral failures involving pastors in Masvingo province. The lived experiences of moral failures by pastors and conflicts that I witnessed motivated me in 2007 to conduct a research project ${ }^{2}$ on conflicts

2.Since the project was an academic requirement for my master's degree in conflict resolution, the University of KwaZulu-Natal provided ethical clearance. 
involving pastors in the AFM in Zimbabwe church. As results from this research showed, conflicts in the church were exacerbated by moral failures of pastors. In the same report I proposed that the AFM in Zimbabwe should consider putting in place a conflict resolution centre to help train pastors, elders, deacons and deaconesses in conflict resolution processes (Chivasa 2012:3-6, 70).

In 2014 and $2015^{3}$ during fieldwork, I worked with a group of 15 adults (eight women and seven men) as my co-researchers in ward 8 of Seke district, Mashonaland East district, Zimbabwe. I collaborated with my co-researchers in creating a 15-member peace committee at ward level. After successfully creating a ward-level peace committee, we mobilised villagers living in villages in the ward and sensitised them to create village peace committees. Of the 16 villages, five successfully created village peace committees by the time of writing my report. From this hands-on experience, I was made to understand that local people have the capacity to take care of their own needs. One outstanding capacity that local people have is to address disputes that arise within their communities.

As a member of the AFM in Zimbabwe in 2017, I took pains to examine the capacities of the church under review in handling acts of misconduct by offending pastors. In this report, it was found that disciplinary measures overlook relationship issues between the offending pastor and the church, thereby plunging the parties involved into nursing antagonistic relations. In the same report, I proposed that a peacebuilding framework should be considered if the church under review is to help repair broken relationships between offending pastors and the church at large during or after a misconduct has occurred me (Chivasa 2017:7). A more recent article examined pastors' moral failures with a strong affirmation that moral failures are not inevitable, and therefore require interventional solutions to help create a morally virtuous AFM in Zimbabwe church. In this article, I argue that moral failure is a spiritual and moral pandemic that requires treatment more than just putting the offender under censure. Further, I propose that pastors' moral failure is an ever-increasing field of mission that the church should do something about, and one way is to come up with a discipleship programme (Chivasa in press). The current article proposes that the church under review could institute dispute resolution procedures (DRP) to mitigate the impact of intrachurch disputes.

\section{Historical development of disciplinary procedures in the Apostolic Faith Mission in Zimbabwe church}

The history of the development of disciplinary procedures in the AFM in Zimbabwe cannot be fully understood without linking it to the 2007 and 2009 strategic planning document,

3.Since this research was part of my PhD, the University of KwaZulu-Natal provided ethical clearance. which culminated in the Policy Document of the Apostolic Faith Mission in Zimbabwe church. The strategic planning exercise was a top-to-bottom approach by a new crop of leadership in the church between 2007 and 2009. The principal goal of the strategic planning exercise was to provide all structures of the church through their provincial councils to participate in and contribute to the four proposed clusters, namely employment policies for pastors and support staff, a code of conduct for pastors and church members, governance system of the church, and financial management system for the church.

Prior to 2007, what was known about disciplinary procedures in the AFM in Zimbabwe was the tradition of putting offenders under censure for a given period without any written-down procedure. The Constitutions (amended in 1976; 1995; and 2001), for instance, outline acts of misconduct (such as excessive or any drinking of liquor, adultery, fornication, divorce, abortion, murder, robbery and fraud), that warrant disciplinary measures. Thus, the coming in of the strategic planning exercise established a precedent for all members of the church to participate in creating a mechanism that was to supplement the Constitution of the church on issues related to pastors' employment conditions, discipline, governance and financial management. As such, the 2007 and 2009 strategic planning exercises involved a rollout in all the 16 provinces by a team of pastors and lay workers representing each province. Since I was a member of the Masvingo provincial council at that time, I participated in the deliberations in shaping the four clusters. All recommendations from the 16 provinces were taken together and the outcomes culminated in what is now known as the Policy Document.

In a significant departure from the Constitution and Regulations, the Policy Document contains the employment policy (Chapter 1), the church governance policy (Chapter 12), the code of conduct and grievance handling procedure (CCGHP; Chapter 14), and the financial management policy (Chapter 15). The role of the Constitution and Regulations has been confined to disciplinary measures and the period of censure (Chapter 16). Thus, one can be pardoned for concluding that by coming up with a Policy Document, including disciplinary procedures, the church had probably realised that Chapter 16 of the Constitution and Regulations was not explicit enough about procedures for handling acts of misconduct. The CCGHP outlined acts of serious misconduct and less serious misconduct (Chapter 14). In outlining both serious and less serious misconduct, unlike the Constitution and Regulations, the CCGHP refined defining acts of misconduct that warrant disciplinary measures and those that warrant counselling, written or verbal warnings.

The disciplinary procedure is not defined in the Policy Document of the Apostolic Faith Mission in Zimbabwe church, but the procedure is presented in a simplified way. Chapter 14.7.4 recommends that: 
Where the case involves a pastor, the provincial board of elders shall appoint at least three members to carry out investigations and upon discovery that a pastor has a case to answer the board shall within 48 hours take the following actions: (1) Counsel, issue a verbal or written warning against the offender. (2). Notify the offender of the nature of his/her offence and date, time and venue of hearing. (3) Suspend the pastor immediately with or without pay and benefits pending outcome of the disciplinary hearing. (4) Advise the pastor of his or her right to representation of his or her own choice of up to two representatives. Offender to make own arrangements with representative and bear the costs of such representation. (Policy Document of the AFM in Zimbabwe church)

Chapter 14 of the Policy Document provides that appeal proceedings could be taken on board if the offender is not satisfied with the proceedings. The disciplinary procedure was instituted in the Policy Document with the intention of making the AFM in Zimbabwe church achieve its aims 'to maintain and promote good order' (Constitution and Regulations, Chapter 1.4.2), and 'promoting harmony and discipline' (Policy Document, Chapter 14.1.1). The disciplinary procedure has achieved its aims with limited success as some cases of misconduct in the church still find their way into the courts of law, indicating that the disciplinary procedure is flouted or challenged.

\section{What is involved in dispute resolution?}

There are biblical bases for dispute resolution in the church. 1 Corinthians 6:1, for example, states that 'if any of you has a dispute with another, do you dare to take it before the ungodly for judgement instead of before the Lord's people?'. There are universally accepted principles that govern dispute resolution that the AFM in Zimbabwe may need to consider. One of the universally accepted principles of dispute resolution is for disputants to agree to adopt a problemsolving approach (Bao et al. 2016:542; Bloomfield, Ghai \& Reilly 1998:38; Geckler, Carney \& Hazler 2016:14; Harris 2007:4; Keethaponcalan 2017:49; Tillett 1999:97). Within this framework, Tillett (1999) advises that

all communities have established mechanisms for resolution of [disputes], even if these are often unwritten and not necessarily explicit. In traditionally, close-knit communities, these may be very clearly defined, although not necessarily formally and possess great authority and antiquity. Some communities have clear leaders whose role in the resolution of [disputes] may be crucial; others work on a less structured and more communal basis. (p. 163)

Disputes involving members of the church under review, for example, could arise between pastors and elders, deacons, deaconesses, or ordinary members themselves. In most cases, these disputes may involve an alleged breach of the Constitutions and Regulations of the church or unresolved grievances. These disputes disrupt the smooth running of church affairs and impose a heavy strain on church resources. As such internal dispute resolution procedures are unavoidable.
The purpose of dispute resolution procedures is to create a user-friendly process in which disputants engage each other in search of a mutually satisfying solution to the problem. For that reason, facilitators need to handle the process with extra care and sensitivity to the needs and interests of disputants to expedite the resolution of the dispute. Resolving the dispute should take into consideration creating an environment that puts disputants in the mood to want to agree to quickly iron out their differences and come up with an agreed solution. The overall goal of dispute resolution is to maintain friendly relations and cordial harmony as well as to reduce the risks of people harbouring animosity and grudges owing to unresolved disputes.

To ensure that friendly relations and cordial harmony are sustained even after a dispute, the process for resolving a specific dispute should be friendly. One major characteristic feature of a friendly process is to afford disputants equal opportunities to tell their stories in a calm and nonthreatening environment. The facilitator should establish a thorough understanding of the dispute and its causes. The perspective of each disputant should be captured from each person's vantage point. In addition, the facilitator should take extra care to assist disputants in coming to an agreed solution to their dispute. Dispute resolution can only be achieved if disputants themselves have successfully agreed on the outcome.

\section{Factors requiring consideration when instituting dispute resolution procedures in the Apostolic Faith Mission}

The AFM in Zimbabwe church needs dispute resolution procedures for multiple reasons. The major one is that the Policy Document of the AFM in Zimbabwe outlines disciplinary measures only (Chapter 14.7), yet when one closely examines this policy, pastors and support staff are governed by a web of regulations, namely employment policy, code of conduct, governance policy and financial administration policy, all of which are sources of disputes. Typically, the employment policy on job evaluation and remuneration states that 'long service will be rewarded through an allowance which is dictated by the length of service from date of ordination and or service in the AFM in Zimbabwe'. The number of years' service to be rewarded are 5, 10, 15, 20, 30 and 35 years, and the equivalent rewarding percentage is $5 \%, 7 \%, 10 \%, 15 \%, 17 \%$ and $20 \%$, respectively (Policy Document, Chapter 4.2). Furthermore, the policy outlines other benefits, which include educational support to pastors in the form fees up to $50 \%$ on all approved educational studies. The policy promises to reward education attained as follows: a pastor with a bachelor's in any ministerial discipline is entitled to a reward of 5\%, master's degree $10 \%$, doctorate $15 \%$ and professorship 20\% (Chapter 8.2).

In addition, for those pastors with children attending school, the policy provides that 
the church shall assist the pastor in school fees payments. This shall be limited to $50 \%$ tuition and levy at public school level and a maximum of four own children. (Chapter 8.3)

For those pastors in rural areas, the policy provides that 'the church shall pay a $15 \%$ of the pastors' basic salary as rural allowance' (Chapter 8.7). These policies are potential sources of disputes, which warrant dispute resolution procedures.

Another factor is the number of members of the AFM in Zimbabwe church. Over the years the number of church members has been on the increase. At one stage statistics showed that the church attracted an estimated 2 million members across Zimbabwe (Machingura \& Chivasa 2016:10). In 2015 when the AFM celebrated 100 years of active ministry, Madziyire \& Risinamhodzi (2015:99-130) acknowledged the widespread and systematic growth of the church over the past decades. Growth was widespread in that province of the church increased from 16 in 2007 (Chivasa 2012:38) to 29 by 2015 (Madziyire \& Risinamhodzi 2015:130). Madziyire and Risinamhodzi estimate that AFM in Zimbabwe church has 728 established assemblies and an equivalent number of 728 pastors, each residing at an assembly. In the Constitution and Regulations of the AFM in Zimbabwe, an assembly represents an organised group of people comprising a minimum of 50 people (both men and women) capable of sustaining the allowance of a resident pastor (Chapter 3.1.1). Statistically an 'established assembly', to use Madziyire and Risinamhodzi's (2015:130) phrase, involves people with the capacity to support the resident pastor through their monthly tithes.

Another factor is that in the AFM in Zimbabwe an established assembly is one that has a resident pastor with a pool of elders, deacons, deaconesses and structures. At each assembly there are structures such as a board of elders, administration board, sister union, youth board, welfare board, men's fellowship board, widows and single mothers board, and children's ministry board. In all these structures the pastor is the ex-officio chairperson. It is important to highlight that individuals in each of the structures have different goals, objectives, values and opinions, and therefore disputes are unavoidable (Lipsky \& Seeber 2006:362).

In addition, the AFM in Zimbabwe is already experiencing disputes related to pastors' transfers and elections of pastors. During informal conversations, disputes relating to pastors' transfers were identified as the most common reason for disputes in the church. Furthermore, in local newspapers disputes relating to pastors' transfers are a common theme. By 2013 local newspapers reported that 'AFM church pastors bribe overseers to be transferred to profitable assemblies' (Staff Reporter 2013a); 'AFM church overseer accused of being used by the devil' (Staff reporter 2013b); 'AFM church members in demo against overseer' (H-Metro 2013). The problem, as one AFM member noted, is that 'there is no engagement between the church leaders and the congregants when it comes to transfer issues' (Koni 2016).

Finally yet importantly, the church under review currently operates without dispute handling procedures. Over the years it appears that the AFM in Zimbabwe has adopted a laissez-faire attitude hoping that pastors and local boards of elders will address disputes as and when they arise or learn to live with disputes. The problem with this approach is that unresolved disputes can grow out of proportion, thereby impeding the church's performance and wellbeing, and drain its resources through lawsuits. The current disciplinary procedures cannot replace dispute handling procedures because the two are not the same. Lipsky and Seeber (2006:363) note that many organisations do not have clear policies for addressing disputes and the AFM in Zimbabwe has not been spared.

\section{Significance of dispute resolution procedures}

The merits of instituting dispute resolution procedures include that they:

- prevent the focus of the AFM in Zimbabwe being diverted from preaching love, mercy, compassion, forgiveness, reconciliation and all the other Christian values;

- encourage local church groups to deal with disputes within their scope at their local level and any dispute that is external should be referred to the responsible authority;

- enable disputes to be dealt with at local church level where they erupt, rather than having to wait for the provincial committee to investigate, discuss the matter in a provincial council and forward its recommendations to the Apostolic Council to decide on that matter;

- allow pastors, elders, deacons and ordinary members to creatively deal with disputes that arise within their own local churches;

- allow local churches to be self-regulatory as dispute resolution can take place at the local level;

- reduce the risk of rumour-mongering because disputes are addressed at the places where they erupt;

- enable the intervention of primary actors at the local church level who are well versed in the dynamics surrounding a specific dispute, to be able to deal with disputes quickly and effectively.

\section{Best practice for effective dispute resolution procedures}

The Christian Bible contains several examples providing models for effective dispute resolution. However, due to space restriction, only two models, one from the book of Acts of the Apostles (New Testament) and the second from Exodus (Old Testament), are considered to briefly illustrate best practices for effective dispute resolution.

Specifically in the Acts of the Apostles 6:1-7, the problem is raised that Greek-speaking Christians felt that the social needs of their widows were not taken care of, while Hebrew widows were alleged to be getting more than their daily share of the food distributed. As a result, Greek-speaking Christians took it upon themselves to raise a complaint on this matter, which caught the attention of the church leaders, the Apostles. In response, a meeting involving the entire 
congregation was called to help resolve the problem around food distribution across the two different ethnic groups of widows. To address the problem, the Apostles in collaboration with the entire congregation created a team of deacons to distribute food equitably between the minority Greek-speaking and majority Hebrew-speaking Christians and the outcome was mutually satisfactory to both ethnic groups.

In Exodus 18:13-24, Jethro advised Moses to delegate responsibilities to fellow Israelites to ensure effectiveness and sustainability in resolution of disputes. The Bible states that

Moses listened to his father-in-law and did everything he said. He chose capable men from all Israel and made them leaders of the people, officials over thousands, hundreds, fifties and tens. They served as judges for the people at all times. The difficult cases they brought to Moses, but the simple ones they decided themselves (Ex 18:24-26).

In a society which was biased towards patriarchy, Moses chose men only. In contrast, in a society which is gender sensitive like ours today, any structure should be mixed, viz. the structure should comprise both men and women. In these two books there are two different models suggested in each case. In the book of Acts of the Apostles, for example, the best practice illustrated is the adoption of a problem-solving approach, which results in a mutually satisfying outcome for all the parties. In the book of Exodus the best practice illustrated is the delegation of responsibilities between individuals and groups. The underlying lesson from these two best practices is the creation of local structures that are accessible to the people that they are intended to serve.

In view of best practices, the current study proposes the creation of a structure. For purposes of this study, the structure could be called the dispute resolution coordinating committee (DRCC). Churches work better with structures and setting up a structure is not in violation of the Constitution and Regulations of the AFM in Zimbabwe (Chapter 1.4.1; 13.6.1).

\section{A model dispute resolution coordinating committee at local assembly level in the Apostolic Faith Mission in Zimbabwe}

The purpose of the DRCC would be to help facilitate the smooth resolution of disputes at local church level. However, for those disputes involving pastors, the overseer should facilitate the creation of a DRCC comprising pastors only. The aim of the pastors' DRCC is to help handle disputes involving pastors in each of the 29 provinces. Overseers too should be ex-officio members of the DRCC at provincial level. The pastors' DRCC will help to relieve the workload already on the shoulders of the provincial committee and enable it to administer provincial conferences and preaching schedules. Similarly, the local boards of elders already have workloads that include preaching, teaching, conducting Bible studies, and visiting and praying for the sick (Constitution and Regulations, Chapter 4.3). In view of the workload already burdening existing structures, this study proposes the following:

- Every local church in the AFM in Zimbabwe should create a DRCC.

- A DRCC should become a liaison platform for all the parties in a dispute to participate in search of a mutually satisfying solution to the dispute.

- Akin to any other structure in the church under review, the DRCC should be elected triennially (Constitution and Regulations, Chapter 4.10).

- A local DRCC should be mixed (comprising both men and women) to achieve gender equality.

The creation of the DRCC is in line with aim 1.4.4 of the Constitution and Regulations of the AFM, which states that it is possible 'to set up various assembly boards, committees or associations where this may be considered necessary'. In fact, not creating a DRCC is not an option for the AFM in Zimbabwe considering that this church does not currently have this institution in place. More so the AFM in Zimbabwe, like any other church community, is exposed to disputes of various proportions and the unavailability of dispute resolution procedures suggests that the church is currently using a trial and error method. The cost (in terms of relationships as well as monetary) of not having DRP would be much higher than having procedures and implementing them fairly and properly. Briefly, local churches should be able to address their own disputes through the DRCC. Creating a local DRCC is one way of acknowledging the capacity of church members to take responsibility for their own disputes as a local church.

I am aware that the AFM in Zimbabwe aims at maintaining good order and harmony. Harmony is not a top-to-bottom value; it is the other way round. When I first collaborated with local communities in creating a 15 -member ward peace committee and five village peace committees in ward 8 of Seke district, Mashonaland East province in Zimbabwe, I learnt that participation of local communities in creating harmony and peaceful relationships is crucial. My research partnership with people in Seke district led me to believe that giving local people the opportunity to participate in creating their own structures is one way of empowering them to take responsibility for their own needs. In this context not only does creating a DRCC increase participation of church members in the design and dispute resolution process, but it generates knowledge for future dispute resolutions. From this hands-on experience the current study gradually moves towards recommending local church-initiated dispute resolution procedures and a directed participation model in which local church members are at the centre of decisionmaking and resolution of disputes that arise at their local church. As a small contribution of how church leadership should acknowledge the capacity of local churches to address disputes occurring at their assemblies, I suggest procedures for setting up a DRCC at assembly level. 
Procedures for creating a DRCC at local church level:

- A provincial facilitator should visit the local church to see the pastor and local elders operating in that specific church. As mentioned already, the creation of the DRCC is in line with aim 1.4.4 of the Constitution and Regulations of the AFM.

- A meeting should be convened with the local board of elders and pastor to secure them to commit to set up a DRCC. As usual the pastor should remain the ex-officio member of this committee.

- Once commitment has been secured the provincial facilitator can provide guidelines such as that a committee should comprise seven people inclusive of men, women and youth as outlined in the Constitution and Regulations.

- The facilitators should explain qualities and tasks that are expected of the DRCC as outlined in 1 Timothy 3:1-7 and Titus 1:5-9. Also included should be social, moral, personality, domestic and spiritual qualities as outlined by Madziyire and Risinamhodzi (2015:148-149).

- Once these criteria are understood, the facilitators should leave the responsibility for selection of the DRCC to the respective local church.

- Emphasis should be that the DRCC should be selected at a public forum on a date stated by the local church.

- The names of the selected members should be given to the secretary of the local church to be kept in the provincial office archive.

These guidelines are only suggestions and are not a prescription. However, the principle remains that to ensure harmony in the church, dispute resolution procedures should be in the hands of local church groups.

\section{Conclusion}

The main purpose of this study is to argue the need to institute dispute resolution procedures in the AFM in Zimbabwe church. Using the systems theory lens, this study established that churches, particularly the AFM in Zimbabwe, are susceptible to disputes. The analysis has shown that the disciplinary procedure in the AFM in Zimbabwe is largely ineffective when it comes to dealing with pastors' transfers and election disputes. Local newspaper headlines in Zimbabwe on pastors' transfers and election disputes point to the scale of the problem, which requires immediate attention. Instituting DRP from local assembly, provincial and national levels will be the ideal option. In addition, this study argues that the church is an open system, and therefore should be flexible enough to keep in step with constantly changing environments. One option is to institute mechanisms that are sensitive to the needs of ordinary church members and pastors as well, because the existing Policy Document addresses issues relating to acts of misconduct not to disputes. As such the Policy Document may need an overhaul to incorporate DRP, which provide clear and specific guidelines on dispute resolution. The advantages of DRP are many. DRP implicates that the church will have a structure comprising peer dispute resolution practitioners.
Establishing a DRP structure guarantees continuity and fosters professionalism, which may lead to effective dispute resolution. Dispute resolution procedures minimise chances of going to courts of law for dispute settlement. This study leaves room for further interrogation in this area.

\section{Acknowledgements Competing interests}

The author declares that he has no financial or personal relationships which may have inappropriately influenced him in writing this article.

\section{References}

Assefa, H., 2001, 'Reconciliation', in L. Reychler \& T. Paffenholz (eds.), Peacebuilding: A field guide, pp. 336-342, Lynne Reinner Publishers, London.

Bao, Y., Zhu, F., Hu, Y. \& Cui, N., 2016, 'The research of interpersonal conflict and solution strategies', Psychology 7, 541-545. https://doi.org/10.4236/psych.2016. 74055

Bloomfield, D., Ghai, Y. \& Reilly, B., 1998, 'Analyzing deep-rooted conflict', in P. Harris \& B. Reilly (eds.), Democracy and deep-rooted conflict: Options for negotiators, pp. 31-48, Institute for Democracy and Electoral Assistance, Stockholm.

Bulla, F., 2015, 'When the church becomes a battlefield', The Sunday Mail, 26 April, viewed 30 May 2017, from http://www.sundaymail.co.zw/when-the-churchbecomes-a-battlefield/

Bulla, F., 2016, 'AFM conference sidesteps local conflicts', The Sunday Mail, 24 April, viewed 29 May 2017, from http://www.sundaymail.co.zw/afm-conferencesidesteps-local-conflicts/

Business dictionary, 2017, Dispute, viewed 29 May 2017, from http://www.dictionary. com/browse/dispute?s=t

Cambridge dictionary, 2017, Dispute, viewed 29 May 2017, from http://dictionary. cambridge.org/dictionary/english/dispute.

Chivasa, N., 2012, The nature, causes and consequences of conflicts involving pastors, LAP Lambert Academic Publishing, Saarbrucken.

Chivasa, N., in press, Interventional solutions to pastors moral failures: A case study of the Apostolic Faith Mission in Zimbabwe church, Harare.

Chivasa, N., 2017, 'Handling pastoral misconduct and discipline: Evidence from the Apostolic Faith Mission church', HTS Teologiese Studies/Theological Studies 73(3), 1-8. https://doi.org/ 10.4102/hts.v73i3.4518

Constitution and Regulations of the Apostolic Faith Mission in Zimbabwe church, Harare.

Duve, R. \& Maitireyi, P., 2011, 'Labour arbitration effectiveness in Zimbabwe' 19 August, viewed 29 May 2017, from http://www.accord.org.za/ajcrissues $/ \% \mathrm{EF} \% \mathrm{BF} \% \mathrm{BClabour}$-arbitration-effectiveness-in-zimbabwe/

Geckler, J., Carney, J.V. \& Hazler, R.J., 2016, 'Social problem solving as a key component of bullying prevention programs', International Journal of Psycho-Educational Sciences 5(3), 12-23.

Gukutikwa, T., 2016, 'AFM church members in ugly fight', Manicapost, 28 October, viewed 29 May 2017, from http://manicapost.co.zw/afm-church-members-inugly-fight/

Harris, G., 2007, Conflict resolution and mediation services in South African universities: A cost benefit analysis, University of Kwa-Zulu Natal, South Africa, Durban, pp. 1-13.

H-Metro, 2013, AFM church members in demo against overseer, 18 January, viewed 29 May 2017, from http://nehandaradio.com/2013/01/18/afm-church-membersin-demo-against-overseer/

Justice Connect, 2015, Dealing with disputes and grievances with members, viewed 23 May 2017, from https://www.nfplaw.org.au/sites/default/files/media/Dealing with_disputes_and_grievances_with_members.pdf

Keethaponcalan, S.I., 2017, Conflict resolution: An introduction to third party intervention, Lexington Books, London.

Koni, L., 2016, 'AMHVoices: AFM does not belong to anyone, but everyone', Newsday, 07 January, viewed 30 May 2017, from https://www.newsday.co.zw/2016/01/07/ afm-doesnt-belong-to-anyone-but-everybody/

Lipsky, D.B. \& Seeber, R.L., 2006, 'Managing organizational conflicts', in J.G. Oetzel \& S. Ting-Toomey (eds.), The Sage handbook of conflict communication: Integrating theory, research and practice, pp. 359-390, Sage, London.

Machingura, F. \& Chivasa, N., 2016, 'Mainstreaming HIV and AIDS programmes in the ministry of the Apostolic Faith Mission in Zimbabwe', Alternation 23(2), 1030.

Madziyire, A. \& Risinamhodzi, T., 2015, Pentecostal dawn in Zimbabwe: The history and tenets of AFM, The Brand Guy and Associates, Harare.

Malhadas, M.J., 2010, 'Organizational conflicts from a general theory of systems point of view', Virus, p. 3, viewed 31 May 2017, from http://www.nomads.usp.br/virus/ virus03/submitted/layout.php?item $=6 \&$ lang $=e n$ 
Miller, R.E. \& Sarat, A., 1981, 'Grievances, claims, and disputes: Assessing the adversary culture', Law and Society Review 15(3-4), 52-62.

Mhlanga, B., 2016a, 'AFM fires senior pastor, closes assembly', The Standard, 03 January, viewed 29 May 2017, from https://www.thestandard.co.zw/2016/01/03/ afm-fires-senior-pastor-closes-assembly/

Mhlanga, B., 2016b, 'Violence mars AFM services as congregants block pastors transfers', Newsday, 04 January, viewed 29 May 2017, from https://www. newsday.co.zw/2016/01/04/violence-mars-afm-services-as-congregants-blockpastors-transfer/

Murwira, Z., 2015, 'Disgruntled members sue AFM executive', The Herald, 14 April, viewed 30 May 2017, from www.herald.co.zw/disgruntled-members-sue-afmexecutive/

Policy Document of the Apostolic Faith Mission in Zimbabwe church, Harare.

Post Reporter, 2016, 'AFM pastor, congregants clash', Manicapost, 18 March viewed 29 May 2017, from http://manicapost.co.zw/afm-pastor-congregantsclash/

Razemba, F., 2016, 'AFM seeks leadership change', The Herald, 01 April, viewed 30 May 2017, from www.herald.co.zw/afm-seeks-leadership-change/

Staff Reporter, 2013a, Bulawayo 24 News, 'AFM church pastors bribe overseers to be transferred to profitable assemblies', 15 January, viewed 29 May 2017, from http://bulawayo24.com/index-id-news-sc-religion-byo-24989.html
Staff Reporter, 2013b, 'AFM church overseer accused of being used by the devil', Bulawayo 24 News, 16 January, viewed 29 May 2017, from http://bulawayo24. com/index-id-news-sc-religion-byo-25048.html

Staff Reporter, 2015, 'Overstaying AFM leader splits church', NewZimbabwe.com, 13 April, viewed 30 May 2017, from www.newzimbabwe.com/news...Overstaying+A $\mathrm{FM}+$ leader+splits+church/news.aspx

Schellenberg, J.A., 1996, Conflict resolution: Theory, research and practice, State University of New York Press, New York.

Tillett, G., 1999, Resolving conflict: A practical approach, Oxford University Press, Oxford.

Von Bertalanffy, L., 1968, General systems theory: Foundations, development, applications, George Braziller, New York.

Zhakata, I., 2016, 'AFM leadership row spills into court', The Herald, 23 March, viewed 29 May 2017, from www.herald.co.zw/afm-leadership-row-spills-into-court

ZimEye, 2015a, 'AFM church in dirty election rigging: Court papers', 13 April, viewed 07 July 2017, from https://www.zimeye.net/afm-pastors-contest-churchspresident-election/

ZimEye, 2015b, 'AFM church hires NIKUV to rig pastors' elections - Members', 14 April, viewed 30 May 2017, from https://www.zimeye.net/nikuv-elections-ripafm-church-apart-members/

ZimEye, 2017, 'Nikuv is back', 24 January, viewed 06 June 2017, from https://www. zimeye.net/2018-elections-nikuv-is-back/ 